\title{
Intra-cultural variation: Explanations in service calls to two Montevidean service providers.
}

\author{
ROSINA MÁRQUEZ REITER
}

\section{Abstract}

This article offers an intra-cultural pragmatic analysis of some aspects of the interactional behaviour of Uruguayans (Montevideans) in non-emergency service calls to two telephone service centres. In both sets of calls customers telephone to confirm delivery of a service for which there has been some delay. In particular, this study investigates the strategies employed by service representatives to apologize for a perceived company's shortfall.

The findings show similarities in the overall organization of both sets of calls as well as in the type of apologizing sub-strategy deployed. Service representatives in both companies coincided in choosing explanations as an expression of remedial work. Although explanations figured in both sets of calls, those given by the call-takers of one of the companies consisted of justifications for the service shortfall and contained explicit expressions of apology, while those of the other company comprised excuses and expressions of evasion of responsibility.

The choice of apologizing sub-strategy is explained by the fact that the offence was regarded as non-severe and by the state of consumer rights in the country. The variation observed in the way the explanations were constructed is attributed to the different micro cultures of the companies.

Keywords: apology; remedial work; justifications; excuses; openings; closings; consumer rights

\section{Introduction}

This article examines the apologizing behaviour of Uruguayan (Montevidean) service representatives in two companies that operate a telephone service centre. In particular, the study focuses on the pragmatic strategies 
employed by service representatives to apologize or not for a perceived company's fault.

The data analyzed are mediated service encounters in which clients telephone a caregiver company and a service repair company to confirm delivery of a service for which there appears to have been some delay. The calls are particularly suitable for the examination of apologizing behaviour as they were triggered by an alleged company's shortfall and one would thus expect to see some apologizing work by the service representatives in an attempt to address (possible) customer dissatisfaction and endeavour to maintain the clientele. The conversational participants, a service representative and a customer, engage in a primarily task-oriented interaction as evidenced by the roles and frames (Goffman 1967) adopted by them and the structure of the calls.

This study seeks to contribute to the body of research that has examined apologizing behaviour in Spanish by providing the first analysis of naturalistic apologies in a Spanish-speaking mediated service context. In particular, it discusses the similarities and differences found in the apologizing behaviour of two groups of participants with similar characteristics in two similar institutional settings in the light of previous research carried out into the expression of apologies by Montevideans (Márquez Reiter 2000, 2001) and into their interactional behaviour in (mediated) service encounters (Márquez Reiter and Placencia 2004; Márquez Reiter 2005, 2006, in press; Márquez Reiter and Stewart in press). In this sense, the goal of this paper is two-fold in that it not only contributes to our knowledge of apologies in Spanish but also aims to inform research into pragmatic variation ${ }^{1}$ as it offers a contrastive intracultural pragmatic perspective on the expression of apologies. Owing to the fact that the data comes from two institutional settings, namely telephone service calls, the patterns observed can be compared with those so far reported in similar intra- and cross-cultural Montevidean institutional settings with a view to establish the extent to which the interactional features observed may be part of the communicative style of Montevideans or whether and where pragmatic variation may exist and which factors might be behind it.

After a brief review of the literature on apologies, the background and methodology of the study is presented. This is followed by an analysis of the apologizing strategies found in the data, and then the conclusion.

\section{Previous research on apologies}

Apologies are a form of remedial action (Goffman 1971), deployed when it is thought that an offence towards another party has been committed or may be committed (Davies et al. 2007). They are expressive acts 
(Searle 1979) by which the speaker (the apologizer) expresses regret for an offence towards someone else (an injured party) and thus accepts moral responsibility for the offence. Therefore, apologies can take place when the speaker believes that some action, which was carried out by $\mathrm{him} / \mathrm{her}$ prior to the time of speaking, has resulted in an infraction towards an affected party who deserves an apology (Searle 1979: 15) and/or when the speaker believes that a future action by him/her may result in an infraction towards the affected party. The primary function of this social act is therefore to remedy an offence caused or about to be caused by the apologizer to the injured party. In this sense, apologies can occur post-event and/or pre-event and have the potential to restore the interpersonal equilibrium.

According to Brown and Levinson (1987) apologies belong to the realm of negative politeness in that they redress face-threatening behaviour and in so doing they acknowledge the addressee's need not be imposed upon and/or offended. Leech (1983) regards apologies as convivial acts aimed at maintaining harmony between the speaker and hearer as they provide some benefit for the hearer (the injured party) and some cost for the speaker (apologizer). Following Scollon and Scollon (1983), Holmes (1990) and my previous work on this subject (Márquez Reiter 2000, 2001), apologies are seen as both face-redressive and face-supportive acts in that by apologizing the speaker may not just redress damage to the hearer's negative face but may also, depending on the context, address his/her own positive face in that by doing so s/he will be portraying an accommodating image of him/herself. In the case of the calls examined here, an apology by the service representative would not only address the rights of the customer but could also potentially address his/ her own (professional) face.

Research into the apologizing behaviour of various cultures has mainly employed adapted versions of Fraser's (1981), Olshtain and Cohen's (1983) and Blum-Kulka et al.'s (1989) taxonomies and has confirmed explicit expressions of apology, admitting fault, promising forbearance, requesting forgiveness and explanations as potential apologetic strategies across various languages. Of these, only explanations figure in the calls examined here with one set of service representatives offering explicit expressions of apology within their justifications for the shortfall and the other offering excuses through which they evaded responsibility.

Some scholars (Scott and Lyman 1968; Schönbach 1980) appear to regard apologies as types of accounts, broadly understood as statements made by a social actor to explain his/her own unanticipated or untoward behaviour or that of others (Scott and Lyman 1968: 112); however, accounts can also be deployed to explain intended offensive behaviour as 
well as other forms of prevention and repair within Goffman's "corrective cycle" (Antaki 1994). Explanations are thus seen here as a choice from the inventory of sub-strategies available to the speaker to apologize. Although explanations constitute a form of accounting, they represent one element in the remedial cycle.

As far as Spanish is concerned, research into apologies has followed studies of apologies in other languages and cultures in that it has been principally conducted from a speech act perspective and employed slightly adapted versions of Olshtain and Cohen's (1983) and BlumKulka et al.'s (1989) coding schemes to elicited data. Ruzickova (1998) is perhaps the exception as far as the corpus of her study is concerned. She conducted the first study into the expression of apologies in (Cuban) Spanish based on field notes and tape recordings. Using Blum-Kulka et al.'s (1989) coding scheme and Brown and Levinson's (1987) positive and negative politeness strategies, she concluded that the Cubans she observed showed a marked preference for positive politeness strategies. These strategies were mainly realized by the giving of explanations including in-group markers and non-intensified hearer-orientated explicit expressions of apology such as Perdóneme la molestia ('Sorry to bother you') ${ }^{2}$. Cordella (1990) examined the apologies performed by Chileans living in Australia in a structured role-play. In this role-play the participants were expected to apologize for having missed a meeting with their boss. Based on the different apologizing strategies found in the literature (Fraser 1981; Olshtain and Cohen 1983; Trosborg 1987; and Holmes 1989), Cordella showed that the Chileans of her study preferred nonintensified hearer-orientated explicit expressions of apology in their desire to support their own positive face while making the hearer a participant of the act. Márquez Reiter's $(2000,2001)$ findings of apologies in Uruguayan Spanish based on the performance of an unstructured open role-play and on Blum-Kulka et al.'s (1989) coding scheme, coincide with the results obtained in other varieties of Spanish as far as the preference observed for non-intensified hearer-orientated explicit expressions of apology. Like Ruzickova (1998), Márquez Reiter also found that the explanations given contained in-group markers and presuppositions of common values thus also expressing positive politeness and a concern for involving the addressee. The quantitative results showed that the apologizing behaviour of the participants of her study was motivated by a combination of social power and severity of offence. It was also found that when the participants have equal power, the severity of the offence becomes weightier thus providing further evidence in support of Wolfson's (1988) bulge theory and highlighting the importance of apologies in symmetrical relationships to redress and support the other. 
Despite differences in corpora, analytical frameworks and dialects examined, the studies which have been carried out so far into the realization of apologies in Spanish(es) show a relatively low incidence of explicit expression of apologies in contrast with those that have been carried out in other languages/cultures (i. e., English). Moreover, non-intensified hearer-orientated explicit expressions of apologies appear to be preferred over intensified hearer-orientated overt apologies and their realization reflects an overall orientation towards positive politeness in interaction. On the other hand, explanations were common. They were given in addition to an explicit expression of apology or in lieu and seem to address positive face concerns.

In this paper apologies are seen as remedial action intended to redress a service shortfall for which the companies are supposedly responsible. The dynamics of apologizing entails that, by apologizing, the speaker not only redresses the hearer's negative face but also potentially supports his/her own positive face; in the case of these calls, the speaker's (professional) face. In apologizing, the apologizer accepts a certain degree of moral responsibility for the offence.

\section{Background and methodology}

The data for this study comes from two Montevidean institutional contexts: a service repair company (SRC) and a caregiver service company (CSC). Both companies are private, deal with middle-class Montevidean speakers ${ }^{3}$ and operate a telephone service centre for customer services. SRC specializes in fixing electronic and media communication equipment (e.g., DVDs, TVs, camcorders, telephones, etc.) and is the official repair centre of a number of well-known international electronic and media communication companies. CSC is a type of health insurance provider whereby clients, that is, (future) patients, pay an annual fee in return for a given period of 'companion care' in the event of being hospitalized (see Márquez Reiter 2005, 2006 for a detailed explanation of caregiver companies).

Although the companies offer different products, both run a telephone service centre, deal with a segment of the Montevidean middle-class population, and are managed and owned by Montevideans. Neither of them offers guidance on how to manage or indeed answer calls. The comparison between the two data sets is therefore based on sameness of situational context in terms of the type of calls (i. e., mainly transactional and institutional rather than relational and private), their (initial) purpose (i. e., to inquire about the delivery of a service), the roles (Drew and Heritage 1992) and frames (Goffman 1967) adopted by the conversational participants (i.e., service representative-customer, institutional 
and non-institutional participant), company procedures (i.e., telephone service centre), type of participants (i. e., Montevidean service providers and Montevidean middle-class customers), dialect spoken (Montevidean Spanish), and lack of call-taker training. Furthermore, the absence of verbal training makes the data particularly suitable for the examination of cultural patterns as it could be argued that the service representatives' verbal behaviour, and most probably that of the customers too, is untainted by (Western) human resource management techniques. Therefore, it could be claimed that the data examined here illustrates what Montevideans think is expected from them in these kind of interactions based on their experience as consumers themselves and on what they see other work colleagues doing. As such, these service calls offer a window into the construction of institutional talk in Montevidean Spanish grounded within the confines of two companies.

In these calls customers telephone to confirm/inquire about the delivery of a service and it emerges in the course of the conversations that there appears to have been some delay on the part of the company. Interestingly, the institutional representatives do not make any attempts to offer any sort of compensation to the customers, offer very few explicit apologies, and procedurally speaking, place the onus on the customer to telephone again in the near future to inquire about any further developments regarding the service they had requested. In the case of one of the companies examined here, CSC, call-takers explicitly evaded responsibility for the delay. Readers unfamiliar with Uruguayan (Montevidean) retail services might think these two companies are illustrative of poor customer service practices. While it is true to say that most Montevideans would judge their services as in need of improvement, they would not find them particularly unusual. To this respect, it is apposite to mention that most companies in the country are not yet answerable to their consumers but to their shareholders (Márquez Reiter 2005: 486), hence gearing their services to the customer needs is not one of their priorities. Although legislation and institutions (i.e., Area de Defensa al Consumidor) to protect the rights of consumers are in place, most Uruguayans do not appear to be aware of them (www.diariola republica.com 3/5/2005) and therefore do not fully exercise them. Added to this is the fact that Uruguay is a small market economy, with circa 3 million inhabitants of which more than half live in Montevideo (www. ine.gub.uy 4/26/2006), where, it would be fair to say, "real" competition is far from abundant. This helps to partly explain the fact that callers do not demand an apology for the delay, request any sort of compensation and accept the fact that the responsibility for telephoning again to inquire about the service they had originally requested rests on them rather than on the company. 
The corpus consists of 30 calls, 15 to CSC and 15 to SRC, recorded in 2002 and 2003 respectively by the companies themselves for monitoring purposes. The calls were answered by 15 CSC service providers and 10 SRC institutional representatives. Permission was granted to use the tapes provided that both the name of the companies and that of their callers remain anonymous. Calls vary in their duration: CSC calls have a median length of 9 minutes while RSC's median call length is 5 minutes. It will be recalled that, call-takers receive very little training. They are verbally instructed to answer the telephone by giving the name of the company and advised to address callers by usted.

The strategies employed to apologize are examined from a sociopragmatic perspective without losing sight of the place in the overall conversation where the apologies occur and how they unfold. To this end, tools of Conversation Analysis are employed. This combination of approaches might be regarded as conflicting in the explanations they put forward of how social interaction occurs (cf. Márquez Reiter 2006), however; an integrated analysis is more informative for the purposes of this study as I claim that some of the practices observed (e. g., the evasion of responsibility by service representatives and its acceptance by the callers) do not just arise out of how the conversational participants negotiate their involvement in the interaction, but are also influenced by the micro culture of the company which, at the same time, is influenced by existing socioeconomic practices (i.e., the state of consumer rights in the country).

\section{Analysis}

The analysis starts with a brief overview of the initial sequences of the calls in order to locate the place in the conversation where apologizing work occurs as well as to gain a flavour of the overall interaction. This is then followed by an examination of the apologizing work exhibited in the calls and a description of the closing sequence.

\subsection{Initial sequences}

In both data sets, apologies were initiated at the beginning of the business exchange (Bailey 1997), following the opening sequence and contingency questions. The opening sequence consisted of the production of a multiunit turn with two and three turn-constructional units (Sacks et al. 1974): organizational identification followed by a greeting, as illustrated at line 1 in example (1), and in some of the CSC calls this was followed by self-identification, as shown at line 1 in example (2). 
(1) RSC

1 CT: Servicio técnico buenas tardes (.) $\uparrow$

Technical service good afternoons

'Service repair good afternoon'

2 C: Sí buenas tardes(.) para saber si ya está pronto un televisor $\uparrow$ Yes good afternoons (.) to know if already ready a television

'Yes good afternoon (.) I'm calling to find out if a TV set is ready'

(2) CSC

1 CT: CSC buenas tardes (.) habla Danila

CSC good afternoons (.) speaking Danila

'CSC good afternoon (.) Danila speaking'

2 C: Hola sí (.) buenas tardes $\downarrow=$ mire yo había pedido una persona $\uparrow(.2)$ para hoy detarde:

Hello yes (.) good afternoons $=\operatorname{look}^{\mathrm{U}} \mathrm{I}$ had asked a person (.2) for today afternoon

'Hello yes (.) good afternoon=I had requested a caregiver (.2) for this afternoon'

3 CT: Sí $\downarrow$

Yes

In all the calls, call-takers responded to the summons by first providing organizational identification in the form of the name of the company and/or department to which the caller had connected (Servicio Técnicol Coordinación de Servicios, CSC) followed by a formal/neutral greeting (Buenos dias/buenas tardes) thus setting the institutional rather than ordinary character of the call from the start (Márquez Reiter 2006). In more than half of the calls to CSC (10 out of 15), call-takers also provided self-identification as shown at line 1 in example (2) above.

The opening sequence was followed by a series of contingency questions (Whalen and Zimmerman 1987) initiated and directed by the calltaker with the aim of locating the service/item required (see lines 3-8 in examples (3) and (4), respectively). Once the necessary information was gathered, the call-taker responded to the reason for the call, as shown at line 9 in example (3) and at line 12 in example (4).

(3) $\mathrm{CSC}$

1 CT: Coordinación de Servicios buenos [días]

Coordination of Services good [mornings]

'Service coordination good [morning]' 
$2 \mathrm{C}$ : [Si] buenos dias $\uparrow$ (.) quiero confirmar una solicitud que hice para hoy $\uparrow$

[Yes] good mornings (.) I want to confirm a request that I made for today

'[Yes] good morning (.) I'd like to confirm a service request for today'

3 CT: A ve:r digame la cédula del socio $\uparrow$

Let's see tell $\mathrm{me}^{\mathrm{U}}$ the identity number of the client

'OK can you give the client's number'

4 C: Ma: le digo $\downarrow=a c a b o$ de pagar X en este momento $\downarrow$ (.) y: este:::: $\uparrow=$ cincuenta y cuatro (.) cuarenta y ocho (.) uno siete se:is $\uparrow$

Ah: I tell you $=$ I've just paid $\mathrm{X}$ this moment (.) and $\mathrm{ah}=$ fifty four (.) forty eight(.) one seven six

'Ah let me see $=$ I've just paid $\mathrm{X}$ at this very moment (.) and $\mathrm{ah}=$ fifty four (.) forty eight(.) one seven six'

5 CT: Guió: $n \uparrow$

Dash

'Dash'

6 C: No: no hay guió: $n \downarrow$

No: no there dash

'No: there is no dash'

7 CT: La Señora María José Gramático:: $\uparrow$

The Mrs María José Gramático

'Mrs María José Gramático'

8 C: E:xactamente $\downarrow$

Exactly

'Exactly'

9 CT: Pero aquí figura el servicio a partir [de mañana]

But here the service appears as [per tomorrow]

'But here it says that the service was booked as [per tomorrow]'

$10 \mathrm{C}: \quad$ [No] a partir de hoy yo pedí

[No] as per today I asked

'[No] I requested to start today'

11 CT: Pero no fue tomado (.)

But it wasn't taken

'But it wasn't processed' 
(4) RSC

1 CT: Servicio técnico buenas tardes $\uparrow$ Technical service good afternoons 'Service repair good afternoon'

2 C: Sí: buenas tarde:: $\uparrow \uparrow=e:: h$ para preguntar por un televisor Sakura $\uparrow$

Yes: good afternoons $=$ ah for to ask for a television Sakur 'Yes good afternoon=I'm phoning to inquire about a Sakura TV set'

3 CT: Si: deme el número de boleta $\downarrow=$ po:r favo:r $\uparrow$

Yes: give $\mathrm{me}^{\mathrm{U}}$ the number of the receipt $=$ please

'Yes give me the receipt number=please'

$4 \mathrm{C}$ : Veintidós $\downarrow$ (.4) dieciocho $\downarrow$ (.2) doscientos cuatro $\downarrow$ Twenty two (.4) eighteen (.2) two hundred and four

$5(1.2)$

6 CT: A nombre de quién es $\uparrow$

In whose name

'What is the name of the person'

7 C: Richard Rodríguez $\uparrow$

Richard Rodríguez

8 CT: Bie:n no corte por favo:r $\downarrow$

OK don't hang up please

'OK bear with me a moment please'

9 (A corta)

10 CT: Ho::la $\uparrow$

Hello

11 C: Holá $\uparrow$

Hello

12 CT: Disculpá la demora $\downarrow=$ mirá está trabajando nuestro departamento técnico aún con él $\downarrow$

Sorry ${ }^{\mathrm{T} / \mathrm{V}}$ for the delay=look they are still working on it our technical department

'Sorry to keep you waiting=look our technical department is still working on it' 
14 CT: No tenemos listo el presupuesto $\downarrow$

We don't have ready the estimate

'We don't have the estimate ready'

$15 \quad(.7)$

$16 \mathrm{C}: \quad[$ Tá: $\uparrow]$

OK

17 CT: [Llama]nos mañana en el correr del día de mañana a ver si:: podemos tener alguna [información $\downarrow$ ]

Call us ${ }^{\mathrm{T} / \mathrm{v}}$ tomorrow during the day to see if we can have any information

'Call us tomorrow during the day to see if we have any further information'

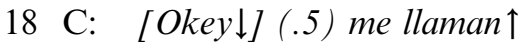

OK (.) you're calling me

'OK (.) will you call me'

19 CT: No:: no:: llamanos tú mañana en la tarde: $\downarrow$ (.7) si:: $\uparrow=$ [antes] de lo previsto:: está el diagnóstico te llamamos nosotros al número que tú dejaste $\downarrow=$

No:: no ::you call us ${ }^{\mathrm{T} / \mathrm{V}}$ tomorrow in the afternoon $(.7)$ if $=$ [before $]$ expected the diagnosis is ready we will call you at the number you left us

'No:: No:: call us tomorrow afternoon(.7) if=we have a report before then we will ring you at the number you've given us'

$20 \mathrm{C}: \quad[$ Tá: $\downarrow]=$ okey $\uparrow$

$[\mathrm{OK}]=\mathrm{OK}$

21 CT: Tá: $\uparrow$

OK

22 C: Tá $\downarrow$

OK

23 CT: Hasta lue:go=adiós $\uparrow$

Until later $=$ good bye

'Good bye $=$ good bye'

In both sets of calls, apologizing work started at the beginning of the business exchange (Bailey 1997). Call-takers responded to the reason for the call with the second pair part of the adjacency pair initiated by the caller in the second turn of the call, as shown in lines 2 and 9 in (3) and 
lines 2 and 12 in (4), respectively. In both sets of calls, the response is dispreferred (Pomerantz 1984). This is evidenced by the presence of the contrast discourse marker pero ('but') in initial position at line 9 in (3), indicating a "contrast" between the semantic meaning of the preceding utterance and the content of that which will follow, and at line 12 in (4) by the inclusion of mirá ('look ${ }^{\mathrm{T}}$ ') within a declarative prefacing some kind of problem/issue (Márquez Reiter 2002). This is further confirmed in the subsequent turn by the caller's silence as a reaction to the bad news, as shown at lines 13 and 15 in (4) and by the customer's overlap at line 10 in (3) when s/he learns that the service had not been requested for today.

In both cases the service representatives' responses, albeit negative in that they do no not address the immediate needs of the customer, were constructed as explanations.

Although both sets of calls are structurally constructed in a similar way, there are differences in the type of explanations given in an effort to offer some remedial work to the customer.

\subsection{Apologizing sub-strategies}

Despite the fact that one could, theoretically speaking, expect some sort of an apology under the circumstances, apologies occurred in relatively low numbers in both sets of calls. When given they were mainly realized by explanations with the inclusion of a few overt apologies functioning as upgraders in the RSC calls as well as ritual apologies for time keeping. On the other hand, CSC service representatives used the shifting of blame as part of their explanations and offered vague and administratively related excuses in an effort not to admit fault, personally or institutionally.

\subsubsection{Explanations}

Explanations were found in all the calls to RSC and in more than half of the calls to CSC (7/15). As pointed out by Fraser (1981), the effectiveness of an explanation given on its own rests on the degree to which the speaker can transfer the responsibility of the offence to another party or source. Bearing in mind the potential for remedial action that explanations can have, it is not surprising that speakers of various cultures, including Spanish, have been shown to use them so often when apologizing.

Although explanations figure in both sets of calls, they differ in a number of ways. There were fewer explanations given by CSC and when given, they were noticeably short, uninformative and merely based on 
what they had in the system without any attempts being made to corroborate the legitimacy of the information, or to try to establish the cause which led to the alleged error/misunderstanding, as illustrated in (5) and (6).

\section{(5) $\mathrm{CSC}$}

12 C: Mire::yo les dije=llamé hasta hoy demañana también y en eso quedamos (.) que la acompañante venía hoy [ mismo] Look ${ }^{\mathrm{U}} \mathrm{I}$ told them $=\mathrm{I}$ called even today in the morning too and that's what we agreed (.) that the caregiver could come today [actually]

'Look that's what I told them $=\mathrm{I}$ even called again this morning and that's what we agreed that the caregiver would come today [actually]'

$13 \mathrm{CT}$ : [Pero] no fue tomado $\uparrow=$ fue tomado para mañana

But it wasn't taken=it was taken for tomorrow

'But it wasn't requested=it's been requested as per tomorrow'

(6) CSC

10 CT: Yo aquí tengo que: (.) el servicio fue tomado a partir del día 9 por la mañana

I have here that (.) the service was taken from $9^{\text {th }}$ in the morning

'The system shows that a caregiver was requested to start on $9^{\text {th }}$ in the morning'

$11 \mathrm{C}$ : Bueno (.) pero mañana que esté la cuidadora ahí

Well (.) but tomorrow the caregiver is there

'OK (.) but make sure that the caregiver will be there tomorrow'

CSC explanations are bureaucratic and one-sided in that the only legitimate source of information is the company's record to which only the call-taker has access (Yo aqui tengo que). The explanations given are impersonally constructed, in the passive case, and lack any interpersonal markers. Moreover, CSC call-takers recurred to transferring responsibility to a third party for the shortfall. As such, their explanations do not address the face concerns of the customer or his/her (theoretical/legal) rights to an efficient and transparent service but their own personal rather than professional face. They are orientated towards making sure that the call-taker in question was not the one who received the original request for service and thus not ultimately responsible for it. 
RSC explanations, on the other hand, were longer and informative in that service representatives let customers know which stage of the process the request was at and when the item in question might be ready for collection, as shown in (7). Some RSC explanations, 6 out of 15, also contained technical information, as illustrated in (8).

(7) RSC

14 CT: [Discul]pe la demora $\downarrow$ (.) están trabajando todavía con él $\downarrow$ en este momento está en manos del técnico: $\uparrow$ e:::h quien (.) por lo que me dijo recién en forma telefónica lo tiene casi solucionado $\downarrow$ (.2) este: y: que de pronto lo vamos a dejar a prueba (.) y:: posiblemente ya quede para hoy pero no le puedo dar seguridad hasta que no quede pronto $\downarrow$

$[\mathrm{So}] \mathrm{rry}^{\mathrm{U}}$ for the delay (.) they are working still with it \at this moment is in the hands of the technician $\uparrow$ um: who (.) from what he said just on the phone has it almost solved $\downarrow$ (.2) um: and: maybe we are going to keep it for testing(.) and: possibly it will be ready today but I cannot give you certainty until it's ready

'Sorry to keep you waiting(.) they're still working on it and it's in the hands of the technician at the moment(.) according to what he's just informed me over the phone it's almost solved(.) and we might keep it for further testing (.) it's possible that it'll be ready today but I cannot guarantee that until it's actually ready'

$15 \mathrm{C}: \quad$ Bue: $=t a ́ \downarrow$

OK then

'OK then'

(8) RSC

$23 \mathrm{CT}$ : e::h como te decía anteriorm:nte lamentablemente no está listo (.) en 48 ho:ras queda pro:nto $\uparrow$ así que podés pasarlo a buscar el viernes directamente $\downarrow$

$\mathrm{Um}$ : as I was telling you ${ }^{\mathrm{T} / \mathrm{V}}$ you before unfortunately it's not ready (.) in 48 hours is ready $\uparrow$ so you ${ }^{\mathrm{T} / \mathrm{V}}$ can come to collect it on Friday

'Um: as I was saying unfortunately it's not ready yet (.) it will be ready in 48 hours and you should be able to collect on Friday'

24 C: Tá: $\downarrow$

$\mathrm{OK}$

'OK' 
25 CT: Sí: lo que está mal no es el display (.) es un problema de alimentación del display

Yes: what is wrong is not the display (.) it's a problem with the input of the display

'The display is not the problem here but the input into the display'

26 C: $\operatorname{Tamos}($.$) tá \downarrow$

$\mathrm{OK}(.) \mathrm{OK}$

'OK(.) OK'

A few of them also contained overt expressions of regret (see first line of (8)), indicating an orientation to redress the customer's negative face. The inclusion of these expressions upgrades the force of the explanations.

Using the distinction drawn by Scott and Lyman (1968) between justifications and excuses in accounts, RSC explanations would be considered to be justifications in that recognition of fault is implicit and what is needed to remedy the situation is in progress. In CSC explanations, fault was also implicitly admitted but personal and/or institutional responsibility for it was denied. Instead, it was transferred to a third party, making these explanations a form of excuse.

In both cases, the explanations offered, though potentially instances of offence remedial actions, expressed little, if any, explicit personal/institutional responsibility for the fault and recognition of customer inconvenience. This, I argue, is probably because the service shortfall was not considered severe by either party at CSC as far as a time offence is concerned, and by the fact that customers are unlikely to demand an apology, let alone compensation for service dissatisfaction bearing in mind the state of consumer rights (see section 3) even in those cases where a "companion" did not turn up when expected.

\subsubsection{Explicit expressions of apology}

Explicit expressions of apology can be realized by a range of apologetic formulas in (Montevidean) Spanish: request for forgiveness perdonamel disculpame $^{4}$, an offer of apology 'lo siento' 'perdonle' 'disculpela' and expression of regret 'lo siento' 'lo lamento'.

Of these formulaic remedies, lamentar occurred 4 times. Lamentablemente (adv.) ('unfortunately') is an expression of regret that can function as a form of explicit apology. It is considered to be the weakest form of overt apology in some languages relative to offers of apology and requests for forgiveness (Suszczynska 1999). Although lamenta- 
blemente semantically expresses regret, in these calls it upgrades the explanation given as evidenced by the place within the turn where it occurs (line 1, (8)) after a reformulator (como te decía anteriorm:nte 'as I was telling you ${ }^{\mathrm{T} / \mathrm{V}}$ you before') and preceding the admission of facts (no está listo 'it's not ready'). Lamentablemente thus functions as discourse marker prefacing the giving of bad news. Its presence boosts the explanation by orienting it towards the hearer's negative face in that it expresses consideration for the customer's inconvenience and an acknowledgement of fault.

Disculpar, the other apologetic formula found in the RSC calls has been shown to be the most common way of offering an apology in Montevidean Spanish (Márquez Reiter 2000). This apologetic verb can mark the distinction between number, formality and informality (T/V) and hearer vs. inclusive orientation according to the presence or not of the object pronoun 'me' as a suffix (Disculpe vs. disculpemé).

In the 3 RSC calls where disculpar occurred, it addressed a virtual offence and was thus a case of a ritual apology (Goffman 1967). Specifically, RSC call-takers, apologized for keeping the caller on hold while they contacted a colleague, in this case a technician, to obtain further information on the service, as shown by the first turn of (9) and (10) below by Disculpe la demora ('Sorry to keep you waiting'). The offence was virtual in that callers were only kept on hold for a maximum of 3 minutes, a period of time that could be said to be acceptable even in monochronic cultures (Hall 1976) of which Uruguay does not form part. Support for this can be found in the fact that the apologies were not even acknowledged by callers, as shown in the second turn of (9) and (10) where the caller focuses on the delay in having the item fixed rather than on having been kept on hold as shown by the overlap when it is announced that there will be a further delay.

(9) RSC

8 CT: Disculpá la demora: $\downarrow$ (.) están [todavía] estudiándolo Sorry $^{\mathrm{T} / \mathrm{V}}$ for the delay (.) they are [still] studying it 'Sorry to keep you waiting(.)they're still checking it'

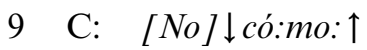

[No] how

'[No] how come'

(10) RSC

7 T: Disculpe la demora caballero $\downarrow$ (.) [están] todavía trabajando con e: $l \uparrow$ 
Sorry ${ }^{\mathrm{U}}$ for the delay gentleman (.) [they are] still working on it

'Sorry for the delay sir (.) they are still working on it'

8 C: $\quad[N o \downarrow]$ có:mo: $\uparrow$

[No] how

'[No] how come'

9 CT: Están todavía trabajando con [el $\uparrow]$

They are still working on [it]

'They are still working on [it]'

The interactional orientation of the RSC representatives to redress customer inconvenience stands in sharp contrast to that of the CSC calltakers who, after their un-informatively brief bureaucratic explanations, washed their hands of the problem and shifted responsibility for the offence to a co-worker.

\subsubsection{Evasion of responsibility}

In almost all the explanations given (12/15), CSC call-taker's resorted to shifting responsibility to a co-worker for the fault, thus they implicitly denied any personal or institutional responsibility for the offence. Specifically, call-takers inquired the name of the call-taker who had originally taken the call, as illustrated in (11) and (12) below, and in most cases, 10 out of the 14, suggested that the caller should telephone again in order to speak to the original call-taker, as shown in (12) below.

(11) CSC

25 CT: Yo entiendo lo que plantea (.) pero la que coordina ya se retiró (.1) no sé con quién hablo usted $\downarrow$

$\mathrm{I}$ understand what you ${ }^{\mathrm{U}}$ are explaining (.) but the person who coordinates has left (.) I don't know with whom you ${ }^{\mathrm{U}}$ spoke

'I understand what you're saying (.) but the person who does this has already left (.) whom did you speak to?'

(12) $\mathrm{CSC}$

30 CT: Usted quiere llamar con la chica que se lo tomó?(.) se llama Ana Laura y está de mañana

$\mathrm{You}^{\mathrm{U}}$ want to call the girl that took it (.) her name is Ana Laura and she's here in the mornings

'Would you like to speak to the lady who took your request(.) her name is Ana Laura and she is here in the mornings' 
31 C: Bue:no (.) yo la voy a llamar $\uparrow$

Well (.) I am going to call

'OK (.) I will call her

32 CT: De ma:ñana llámela porque ( ) $\downarrow$

In the morning call ${ }^{\mathrm{U}}$ her because

'Call her in the morning because'

33 C: Bueno $\downarrow$

Well

'OK'

34 CT: Ana Laura se llama

Ana Laura she's called

'She's called Ana Laura'

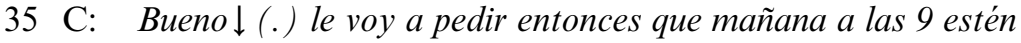
ahí entonces

Well (.) I'm going to ask you then that tomorrow at 9 they are there so

'OK(.) I'd like to ask you make sure that they are there tomorrow at 9 '

36 CT: Sí (.) quédese tranquila que mañana a las 9 (.) alguien tiene que haber

Yes (.) stay ${ }^{\mathrm{U}}$ calm that tomorrow at $9($.$) someone will have$ to be there

'Yes (.) rest assured tomorrow at 9 someone will be there'

37 C: Bueno=muy bien

Well $=$ very well

'OK then'

Call-takers explicitly stated an understanding of the customer's situation, as illustrated in (11) but indicated that they have not got the authority and/or ability to make the necessary amends (pero la que coordina ya se retiro 'but the person who coordinates has left') and passed the responsibility to a fellow call-taker, who by virtue of his/her role as calltaker rather than coordinator will not be able to do anything either (Usted quiere llamar con la chica que se lo tomó $\uparrow($.$) se llama Ana Laura$ $y$ está de mañana 'Would you like to speak to the lady who took your request(.) her name is Ana Laura and she is here in the mornings').

It would be fair to say that CSC call-takers do not fully assume their roles as institutional representatives. They do not admit that an administrative fault was committed and seem more interested in denying personal responsibility for the possible fault than in addressing the custom- 
er's inconvenience. Beyond reflecting poor customer practice, this behaviour shows little allegiance/feeling of belonging to the institution and the responsibilities/duties that this may entail. The evasion of responsibility intensifies the lack of customer orientation exhibited in the excuses provided. As such, these excuses offer very little, if any, remedial work as far the customer is concerned. Interestingly, this behaviour does not seem to take the customer by surprise who agrees to telephone the original call-taker, as can be observed in (12). The occurrence of evasion of responsibility in the CSC calls only is not only explicable in terms of the micro cultures of the companies but also in terms of the type of service which has failed to materialize as it is more difficult to attribute the source of blame for CSC representatives than it is for RSC service providers.

After the explanations were given, the closing sequence was initiated. In the case of the CSC calls, the shifting of blame was followed by expressions of appeasement by the call-taker through which a new delivery date was confirmed. Sequentially they preceded the uttering of warrants and form part of the closing sequence. They consisted in a confirmation that the service will be provided, in this case that a caregiver will be there, and a reassurance realized by quedarse tranquilola ('rest assured'), as illustrated in (13) and (14) below

\section{(13) $\mathrm{CSC}$}

35 CT: Quédese tranquila que a las 9 de la mañana va la acompañante

$\mathrm{Stay}^{\mathrm{U}}$ calm that at 9 in the morning the caregiver is going 'Rest assured that the caregiver will be there at 9 am'

(14) $\mathrm{CSC}$

32 CT: Quédese tranquilo señor (.) la solicitud está tomada de 18.00 en adelante

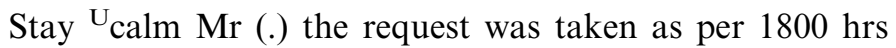
onwards

'Rest assured sir (.) your request has been processed from 1800 hrs onwards'

That a reassurance such as 'quedarse tranquilo/a' ('rest assured') was used could be indicative of the type of calls examined, where callers could be anxious and/or nervous as they are telephoning to confirm that a caregiver has been booked to attend to their loved ones in a particular hospital and their anxiety was exacerbated by the behaviour of the call-taker. It is also an implicit acknowledgment of fault by virtue of its semantic meaning and its sequential placement, that is, it precedes the confirm- 
ation of a new service in the closing sequence of the interactions. It is through the expression of appeasement and the subsequent confirmation of a new service that CSC callers revert to their conversational role as service providers having previously distanced themselves from the cause of problem by shifting the blame onto a third party. The reassurance seems to be accepted, the closing sequence initiated, and the error therefore corrected by default, that is, without explicitly acknowledging the company's error.

\subsection{Closing sequence}

Explanations were followed in both sets of calls by the production of warrants (Schegloff and Sacks 1974), followed, where necessary, by arrangements (Schegloff and Sacks 1974), expressions of gratitude, and, leave-taking utterances as illustrated in example (10) reproduced below.

(10) RSC

10 CT: Disculpe la demora caballero $\downarrow$ (.) [están] todavía trabajando con $e: l \uparrow$

Sorry ${ }^{\mathrm{U}}$ for the delay gentleman (.) [they are] still working on it

'Sorry for the delay sir (.) they are still working on it'

$11 \mathrm{C}: \quad[N o \downarrow]$ có:mo: $\uparrow$

$[\mathrm{No}]$ how

' $[\mathrm{No}]$ how come'

12 CT: Están todavía trabajando con [el $\uparrow]$

They are still working on [it]

'They are still working on [it]'

$13 \mathrm{C}:$ [Bue]no

[Wel]1

'[OK]'

14 CT: Le vamos a pedir si:: no es molestia para usted que nos llame mañana a ver si para mañana quedó pronto $\downarrow$

We are going to ask you ${ }^{\mathrm{U}}$ if it's not a bother to you ${ }^{\mathrm{U}}$ that you call us tomorrow to see if for tomorrow will be ready 'We are going to ask you if it's not too inconvenient for you to call us again tomorrow to see if it's ready'

$15 \mathrm{C}: \quad B u e n o \downarrow t a ́ \downarrow$

Well OK

'OK OK' 
16 CT: Gra:cias

Thanks

'Thanks'

17 C: Hasta luego

Until later

'Good bye'

$18 \mathrm{CT}$ : Hasta luego $=$ adiós $\downarrow$

Until later $=$ good bye

'Good bye $=$ good bye'

The closing sequence was initiated by the callers with the production of a warrant such as Bueno ('Okey') at line 12 and Bueno/Tá $\downarrow$ '('Well Okey') at line 15 , immediately after learning that there had been a delay in the delivery of the service. These warrants are boundary markers indicating a shift of direction in the conversation. They function as pre-closing devices $^{5}$ signalling the speaker's desire to bring the conversation to an end. Pragmatically speaking, the fact that they were uttered with descending pitch and as a reaction to 'bad news' indicate that the customer accepts the state of affairs, resigns him/herself to the fact that the service is not ready, and that the onus of finding out when it will be ready rests on him/her, as illustrated at line 14 by the arrangement and the caller's response at line 15 . The production of pre-closing devices allow the coparticipant to close the conversation or to introduce a new topic, in the case of (10), the call-taker utters an arrangement for future action, a point to which we shall return in brief. Warrants were realized in both data sets by bueno bárbaro ('okey excellent'), bueno muy bien ('okey very well'), muy bien ('very well'), tá okey ('okey okey'), tá tamos ('okey okey'), bueno tá ('okey okey') and tá ('okey'). Most of the pre-closing devices found in the corpus were intensified by means of adjectives (i.e., bárbaro), adverbs (i.e., muy) or by the production of two consecutive pre-closing devices (i. e., tá okey, tá tamos) where, theoretically speaking, only one should be necessary to signal the speaker's desire to bring the conversation to a close.

Although it could be argued that the production of intensified warrants may be a reflection of a positive customer experience (cf. Albert and Kessler 1978), in the case of these calls, it will be recalled that customers telephoned to confirm delivery of a service for which there has been some delay. Hence, this preliminary explanation can be discarded. A second explanation, and one I subscribe to, can be attributed to the relative degree of 'verbosity' and 'effusiveness' observed in the interactional behaviour of Montevideans in service encounters with strangers for the strategic or instrumental purpose of obtaining a service which, 
theoretically speaking, they are entitled to have (Márquez Reiter and Placencia 2004; Márquez Reiter 2005, 2006). Therefore, the presence of intensified pre-closing devices despite a relatively 'unsatisfactory' consumer experience, may suggest that this is a feature of the communicative style of Montevideans. It would then follow that the occurrence of non-intensified pre-closing devices may be interpreted as marked communicative behaviour. In this respect, it is interesting to note that in other calls to CSC, not examined here, where customers telephone to complain about the quality of the service, pre-closing devices are not intensified. An analysis of these closings would be needed to substantiate this observation.

In 2 out of the 15 CSC calls and in 8 out of the 15 RSC calls examined here, after responding to the reason for the call, call-takers initiated arrangements for future action, as shown at line 14 in example (10) above. As Schegloff and Sacks (1974) explain, making arrangements is one of the many possible components of closings in everyday telephone calls and may include re-invocations of materials talked about earlier. In these calls, the reason for the call is subsumed in the arrangement, as the service originally requested has yet to be delivered and it will be up to the caller to telephone again to check if/when it is ready for collection and/or that a caregiver has been confirmed/booked. In both data sets, it was the call-taker who initiated arrangements as a result of companies' procedures. The production of arrangements after the uttering of warrants further orients the call-takers' contributions to the completion of the call while still allowing co-participants to initiate further talk. It could be argued that had the service been delivered on time, arrangements would not have been uttered. In this sense, this component is not essential for the sequence to be closed in that it emerges as a result of the companies' procedures.

Expressions of gratitude which, theoretically speaking, one would expect to occur in service calls of the kind examined here, especially by calltakers, did not figure in all the closings. Where expressions of gratitude occurred, in 8 out the 15 calls to RSC and in 11 out of the 15 calls to CSC, only a first pair part was produced. They were initiated by either call-takers or callers and almost equally distributed between them. They were realized in both data sets by the neutral gracias ('thank you') and in a few cases, 2 out 15 in CSC calls and 1 out 15 in RSC calls, by the slightly more formal le agradezco ('I'm grateful'). Structurally, they occurred after warrants and before the production of leave-taking utterances, as shown at line 16 in example (10) above, accompanying warrants, as shown at line 12 in example (15) below, or accompanying leavetaking utterances, as shown at line 15 in example (16) below 
(15) CSC

12 C: $\quad$ Tá $=$ gracias $\uparrow$

$\mathrm{OK}=$ thanks

' $\mathrm{OK}=$ thanks'

13 CT: Por favor $=$ Buenos días $=$ [adiós $]$

Please $=$ good mornings $=[$ good bye $]$

'Not at all $=$ good bye $=[$ bye $]$

$14 \mathrm{C}: \quad$ [Hasta] lue:go: $\downarrow$

[Until] later

'Good bye'

(16) RSC

15 C: Bue:no=tá $\downarrow$

Well $=\mathrm{OK}$

' $\mathrm{OK}=\mathrm{OK}$ '

16 CT: Hasta luego $=$ adiós

Until later $=$ bye

'Good bye $=$ bye'

17 C: Gracias=hasta luego

Thanks $=$ until later

'Thanks $=$ good bye'

That expressions of gratitude, though relatively prominent, did not figure in all the closings, and when they did they were mainly characterized by containing only one pair part, suggests that they are neither seen as a structurally essential way of bringing the conversation to a close, nor necessarily as a preliminary stage to the terminal exchange. Their frequency and place of occurrence within the closing sequence and the fact that they are neutrally constructed and non-intensified, suggests that rather than address a 'debt/favour' they mark routine politeness and that, if left unuttered, the conversation would still proceed to a close and none of the parties would be offended. It is also noteworthy that topic initial elicitators (Button 1987) such as 'Anything else I can do for you?' and ritualized expressions of gratitude such as 'Thank you for calling' which appear to be common practice in service calls in other languages/ cultures (i.e., English) are not present here. This, I argue, is not just a reflection of customer care practices but also of the amount of politeness investment deemed necessary in the interaction.

The terminal exchange was realized in both sets of calls by leave-taking utterances. Unlike expressions of gratitude, they contained a second pair part. Leave-taking utterances took the form of neutral hasta luego ('see 
you later'), buenos días ('good morning') and adiós ('good bye') thus, in keeping with the neutrality/formality exhibited during the service call and with the purpose of the call, they are mainly transactional rather than relational. The production of a second pair part structurally mirrors the presence of greetings at the initial stages of the interaction and pragmatically conveys routine politeness. In producing them, participants mark "the establishment or perpetuation of a social relationship, the recognition of the other person as a social entity, a personal element in a common social situation" (Firth 1972: 2). The greetings and leavetaking utterances observed reflect and perform the establishment and termination of a relationship: a temporary transactional business relationship with a stranger. Greetings and leave-taking utterances are especially related to the expression of simpatia, a personal quality by which individuals are seen as likeable (Triandis et al. 1984), and are therefore oriented towards the positive end of politeness (Brown and Levinson 1987). Structurally speaking, greetings and leave-taking utterances are not essential for the task to be achieved; nevertheless, they figure in all calls. This suggests that they are socioculturally relevant and a standing practice likely to be found in other (non) institutional contexts.

\section{Conclusion}

The foregoing analysis shows, on the one hand, similarities in the way in which the calls are structured in the two sets of data and, on the other hand, differences in the type and amount of apologizing work exhibited. The sequential similarities observed in the beginnings, the initiations of apologizing work and in the ends of the calls could be explained by the fact that they are "ritualistic" in that they are performed according to "appropriate patterned behaviour" (Rothenbuhler 1998: 27) and, therefore, they are less likely to be generated in the middle of the exchange or in the negotiation of the business exchange, where explanations occurred. It is in the negotiation of the business exchange that distinctive company practices are most likely to emerge.

The structural similarities observed here are consistent with the results found in Montevidean face-to-face service encounters (Márquez Reiter and Placencia 2004; Márquez Reiter and Stewart in press) so far as the briefness of the openings relative to that of the closings and the inclusion of greetings and leave-taking utterances are concerned. This suggests that these patterns may be characteristic of a Montevidean communicative style and are thus likely to emerge in other institutional contexts of this kind, despite differences in the corpora, for example face-to-face rather than over the phone service encounters, and differences in the 
participants, for example lower-middle class/working class rather than middle-class.

Variation, on the other hand, was principally observed in the apologizing behaviour of the call-takers. Although call-takers in both sets of data coincided in offering explanations for the shortfall rather than choosing any other strategy to apologize, differences were observed in the type of explanations given by them. While RSC call-takers offered justifications containing technical explanations for the delays, CSC representatives gave excuses where a third party was made responsible for the shortfall. Specifically, RSC explanations showed an orientation towards the customer's negative face. The justifications provided were effective in transferring the responsibility for the shortfall to another party, in this case RSC's technical department, and seemed trustworthy and/or sincere (Robinson 1996). Moreover, institutional responsibility for the offence was (implicitly) assumed and routine politeness marked by the presence of expressions of regret to intensify the justifications offered and redress the customer's negative face. On the other hand, the excuses given by CSC service providers were one-sided, showed procedural inefficiency and call-takers evaded personal and institutional responsibility for the shortfall, thus not fully assuming their roles as institutional representatives. In this sense, the explanations given by CSC offered very little, if any, remedial work.

Overall, in both sets of calls, there is a relatively low frequency of explicit expressions of apologies, such as offers of apology and overt expressions of responsibility such as (It's our fault). This is perhaps not surprising, considering that their performance would put companies in a position of undisputed fault hence damaging their image and, in some cultures, possibly opening the door for compensation. What the service calls examined here show is that a large amount of apologizing work was not deemed necessary as the offence was possibly seen as non-severe in that it was triggered by an administrative hiccup which will eventually be remedied. Furthermore, these calls show that explanations on their own, rather than accompanying other apologizing strategies, were deemed appropriate by call-takers and, more importantly, by callers.

That customers not only accepted the explanations given but also agreed to telephone again to find out when the service would be ready, not only reflects the fact the offence was not considered severe by either party, but also shows the lack of awareness that most customers have with respect to their statutory rights (see Márquez Reiter 2005), and the rather complacent attitude of some companies towards their customers due to a lack of real competition in what is considered to be a small economic market for investment. It could thus be claimed that lack of sensitization to, and a relatively lagging provision of, consumer rights, 
as far as their implementation and/or enforcement is concerned, has an effect on the participants' choice of apologizing sub-strategies. It would then follow that companies where call-takers receive training to manage calls and/or companies that offer a consumer rights led service, are likely to have different interactional practices. The differences in the apologizing behaviour of call-takers in the two sets of data is, I argue, attributable to the nature of the service which failed to materialize and to differences in company practices rather than to the type of call or call-taker style

Despite having ensured that the pragmatic analysis presented here took into account methodological criteria such as sampling adequacy (not just in terms of possible explanatory variables such as the type of dialect examined and biosocial factors of the participants, but also the time when the data was recorded since interactional practices may change as society changes), other factors, such as the economic practices and institutions of the social group examined, were shown to impact on the conversational behaviour of the participants, both at the micro culture level of the companies and at the macro level of economic practices (i. e., consumer rights).

Finally, the findings are based on a relatively small sample of calls and in a communicative context represented by two given companies. It is only after examining a large enough number of Montevideans across a range of (institutional) contexts that we will be able to ascertain whether the patterns observed so far are representative of a Montevidean communicative style. Nevertheless, it is hoped that these observations provide fruitful possibilities for further studies using larger scale corpora and that they can inform inter- and cross-cultural pragmatic variation studies.

\section{Notes}

1. Sociopragmatic variation is understood as "the way in which speakers vary their use of language in similar situational contexts with similar communicative purposes and thus exhibit different interactional features/patterns" Márquez Reiter and Placencia (2005: 192-3).

2. Perdóneme la molestia could be regarded as an attention getter rather than an apology per se despite the inclusion of an apologetic verb, because it prefaced a request for information rather than addressed an offence, making it subordinate to the request for information being pursued. Moreover, it could be argued that the orientation expressed by perdóneme is inclusive rather than hearer-orientated (perdone) by virtue of the inclusion of the object pronoun me as a suffix.

3. This information was gathered from the Director of the service repair company and the General Manager of the caregiver company.

4. The inclusion of the object pronoun in disculpela perdonela is what differentiates a request for forgiveness from an offer of apology in (Montevidean) Spanish.

5. Schegloff and Sacks (1974: 246) refer to these as 'possible pre-closings' since the initiation of a closing section is only one of the uses they have. 


\section{Transcription Conventions}

[ beginning of overlap

] end of overlap

$=$ latching

- indicates a cut off of the prior word or sound

underscoring indicates emphasis

$::$ indicates pitch rise

INCREASED VOLUME is indicated by capital letters

$\downarrow$ indicates falling intonation

$\uparrow$ indicates rising intonation

( ) indicates inaudible talk or sound which could not be interpreted

\section{Grammatical Glosses}

$\mathrm{T} / \mathrm{V}$ indicates the use of the familiar second person singular tú and/or vos

$\mathrm{U}$ indicates the use of the unfamiliar second person singular usted

\section{References}

Albert, Stuart and Suzanne Kessler (1978). Ending social encounters. Journal of Experimental and Social Psychology 14: 541-53.

Antaki, Charles (1994). Explaining and Arguing. The Social Organization of Accounts. London: Sage.

Bailey, Benjamin (1997). Communication of respect in interethnic service encounters. Language in Society 26: 327-356.

Blum-Kulka, Shoshana, Juliane House, and Gabrielle Kasper (1989). Cross-Cultural Pragmatics: Requests and Apologies. Norwood, N.J.: Ablex.

Button, Graham (1987). Moving out of closings. In Talk and Social Organization, G. Button and J. Lee (eds.), 101-151. Clevedon: Multilingual Matters.

Cordella, Marisa (1990). Apologizing in Chilean Spanish and Australian English: A cross-cultural perspective. Australian Review of Applied Linguistics, 7: 66-92.

Davies, Bethan; John Merrison, and Angela Goddard (2007). Institutional apologies in UK higher education: Getting back into the black before going into the red. Journal of Politeness Research 3 (1): 39-63.

Drew, Paul and John Heritage (1992). Talk at Work: Interaction in Institutional Settings. Cambridge: Cambridge University Press.

Firth, Raymond (1972). Verbal and bodily rituals of greetings and parting. In The Interpretation of Ritual: Essays in Honour of A. I. Richards, J. S. La Fontaine (ed.), 1-38. London: Tavistock.

Fraser, Bruce (1981). On apologising. In Conversational Routine, Florian Coulmas (ed.), 259-271. The Hague: Mouton de Gruyter.

Goffman, Erving (1967). Interactional Ritual: Essays on Face-to-Face Behaviour. New York: Anchor Books.

Goffman, Erving (1971). Relations in Public. London: Allen Lane.

Hall, Edward (1976). Beyond Culture. New York: Anchor Books.

Holmes, Janet (1989). Sex differences and apologies: One aspect of communicative competence. Applied Linguistics 10 (2): 194-213. 
Holmes, Janet (1990). Apologies in New Zealand English. Language in Society, 19 (2): $155-199$.

Márquez Reiter, Rosina (2000). Linguistic Politeness in Britain and Uruguay. Amsterdam: John Benjamins.

Márquez Reiter, Rosina (2001). The case of apologies in English and Spanish. In Perspectivas recientes sobre el discurso. Ana Moreno and Vera Colwell (eds.). Universidad of Leon: AESLA.

Márquez Reiter, Rosina (2002). A contrastive study of conventional indirectness in Spanish: Evidence from Peninsular and Uruguayan Spanish. Pragmatics 12: $135-51$.

Márquez Reiter, Rosina (2005). Complaint calls to a caregiver service company: The case of desahogo. Intercultural Pragmatics 2 (4): 481-513.

Márquez Reiter, Rosina (2006). Interactional closeness in service calls to a Montevidean carer service company. Research on Language and Social Interaction 39 (1): $7-39$.

Márquez Reiter, Rosina (in press). How to get rid of a telemarketing agent: Facework strategies in an intercultural service call. In Face, Communication and Social Interaction, Francesca Bargiela-Chiappini and Michael Haugh (eds.). London: Equinox.

Márquez Reiter, Rosina and María E. Placencia (2004). Displaying closeness and respectful distance in Montevidean and Quiteño service encounters. In Current Trends in the Pragmatics of Spanish, Rosina Márquez Reiter and María E. Placencia (eds.), 121-55. Amsterdam: John Benjamins,.

Márquez Reiter, Rosina and María E. Placencia (2005). Spanish Pragmatics. Basingstoke: Palgrave/Macmillan.

Márquez Reiter, Rosina and Miranda Stewart (in press). Interactions en site commercial à Montevideo (Uruguay) et à Edimbourg (Royaume Uni): "engagement" (involvement) et "considération envers les autres" (considerateness). In Les Interactions en Site Commercial: Invariants et Variations, C. Kerbrat-Orecchioni and V. Traverso (éds.). Paris: Editions du CNRS.

Olshtain, Elite and Andrew Cohen (1983). Apology: A speech act set. In Sociolinguistics and Language Acquisition, N. Wolfson and E. Judd (eds.), 18-35. Rowley, Mass.: Newbury House.

Pomerantz, Anita (1984). Agreeing and disagreeing with assessments: Some features of preferred/dispreferred turn shapes. In Structures of Social Action: Studies in Conversation Analysis, J. M. Atkinson and J. Heritage (eds.), 57-101. Cambridge: Cambridge University Press.

Robinson, W. Peter (1996). Deceit, Delusion, and Detection: Language and Language Behaviour Series. (Vol. 6). Thousand Oaks, CA: Sage.

Rothenbuhler, Eric (1998). Ritual Communication: From Everyday Conversation to Mediated Ceremony. Thousand Oaks, CA: Sage.

Ruzickova, Elena (1998). Apologies in Cuban Spanish. In Proceedings of the First Hispanic Linguistics Colloquium, J. Gutiérrez-Rexach and J. del Valle (eds.), 126149. Columbus: Ohio State University.

Sacks, Harvey, Emanuel Schegloff, and Gail Jefferson (1974). A simplest systematics for the organization of turn-taking for conversation. Language 50: 696-735.

Scollon, Ron and Suzanne Scollon (1983). Face in interethnic communication. In Language and Communication, J. Richards and R. Schmidt (eds.), 156-188. London: Longman.

Scott, Marvin and Stanford Lyman (1968). Accounts. American Sociological Review, 33: $46-62$.

Schegloff, Emmanuel and Harvey Sacks (1974). Opening up closings. In Ethnomethodology. Selected Readings, Roy Turner (ed.), 233-264. Middlesex: Penguin. 
Schönbach, Peter (1980). A category system for account phases. European Journal of Social Psychology 10: 195-200.

Searle, John (1979). Expression and Meaning: Studies in the Theory of Speech Acts. Cambridge. Cambridge University Press.

Suszczynska, Malgorzata (1999) Apologizing in English, Polish and Hungarian: Different languages, different strategies. Journal of Pragmatics 31: 1053-1065.

Triandis, Harry, Gerardo Marín, Judith Lisansky, and Hector Betancourt (1984). Simpatía as a cultural script of Hispanics. Journal of Personality and Social Psychology 47: $1363-1375$.

Trosborg, Anna (1987). Apology strategies in native/non-natives. Journal of Pragmatics 11: $147-167$.

Whalen, Marilyn and Don Zimmerman (1987). Sequential and institutional contexts in calls for help. Social Psychology Quarterly 50: 172-185.

Wolfson, Nessa (1988) The bulge: A theory of speech behaviour and social distance. In Second Language Discourse: A Textbook of Current Research, J. Fine (ed.), $21-$ 38. Norwood, N.J.: Ablex 
Brought to you by | University of Surrey George Edwards Library (University of Surrey Geo Authenticated | 172.16.1.226

Download Date | 3/9/12 11:30 AM 